Journal of Research in Technical Careers

May 2020, Vol. 4, No. 1.

(C) Author(s)

\title{
Teaching Students with Special Needs in School- Based, Agricultural Education: A Historical Inquiry
}

\author{
Kathryn L. Teixeira, M. Craig Edwards \\ Oklahoma State University
}

\begin{abstract}
The purpose of this historical study was to investigate the inclusion of students with special needs in schoolbased, agricultural education as reported by The Agricultural Education Magazine and the Journal of Agricultural Education over a time period of six decades. The impact of landmark legislation, such as the Vocational Education Act of 1963, the Elementary and Secondary Education Act of 1965, the Education for All Handicapped Children Act of 1975, and the Individuals with Disabilities Act of 1990, were examined. This legislation motivated and supported agricultural education's efforts to meet the learning needs of special education students by providing modified lessons and learning environments, inclusive SAEs and FFA activities, and focused teacher preparation. Challenges and concerns regarding the placement of special needs students in school-based, agricultural education are also discussed, as well as opportunities for related research in the future, especially about their participation in the FFA.
\end{abstract}

Keywords: special needs students, school-based agricultural education

\section{Introduction}

A young man walked the show barns of his county fair wearing the blue corduroy jacket of the National FFA Organization (FFA). He spent the last three months raising a Boer meat goat, maintaining the feed and water, and, with his father, built a shelter for the animal some called a goat mansion. Although he was a person with Asperger's Syndrome, he attended general education classrooms learning from normal teachers, interacting with normal children, and just being normal. He was born in a time when it was not uncommon for students with special needs to be placed in normal classroom settings. However, 90 years ago when the National FFA Organization was founded as the Future Farmers of America, he might not have been enrolled in public school, and less likely to become a member of the FFA.

Agricultural education began to receive regular federal funding in 1917 with the enactment of the Smith-Hughes Act, also known as the National Vocational Education Act (Smith-Hughes Act of $1917 \S$ Pub. L. No. 64-347 § 10). In 1928, 11 years later, 33 farm

(i) $\ominus$ Creative Commons CC-BY-NC-ND: This article is distributed under the terms of the Creative Commons Attribution 4.0 License (http://creativecommons.org/licenses/by/4.0/) which allows others to download your works and share them with others as long as they credit you, but they can't change them in any way or use them commercially. 
boys came together from 18 states to form what is known today as the National FFA Organization (2018a). Through the Official FFA Manual and other resources, FFA members learn about an organization that has seen students from every walk of life achieve "premier leadership, personal growth, and career success through agricultural education" (National FFA Organization, 2018b, p. 8).

Today, school-based, agricultural education (SBAE) provides opportunities for students to learn through classroom and laboratory instruction, supervised agricultural experiences (SAEs), and FFA activities (Cano \& Moore, 2010). Students are FFA members regardless of their race, religion, or gender, but that was not always the norm, i.e., "the established behavior patterns for the members of a social system" (Rogers, 2003, p. 26), or in this case, U.S. public schools. The National FFA Organization, once considered strictly for farmers and rural students, has transitioned to become more inclusive by promoting diversity across cultures and learning abilities (Faulkner \& Baggett, 2010).

During its history, SBAE and the National FFA Organization faced large social movements fomenting pivotal moments of cultural change. In 1935, the New Farmers of America (NFA) was founded to create an organization for African American students (Wakefield \& Talbert, 2003) at a time when school segregation based on race existed throughout most of the United States. The NFA merged with, or rather was subsumed by, FFA in 1965 (Wakefield \& Talbert, 2003). Coinciding with the women's liberation movement of the 1960s, females were officially permitted to join the organization in 1969, and the organization elected its first female president in 1983 (National FFA Organization, 2018b; Wakefield \& Talbert, 2003). And, in 2017, the organization chose an African American female for that office, a milestone in its storied history (National FFA Organization, 2018a). These changes to the organization's norms were prefaced by historical events in U.S. education and society. Rogers (2003) explained that new ideas and innovations are introduced because of "[s]ocial changes and the social problems facing the world" (p. xix). He also asserted that changes "require a lengthy period of many years from the time when they become available to the time when they are widely adopted" (p. 1). Along with the sweeping social changes of the 20th century that impacted SBAE, including the FFA component, key legislative and historical events also sped the inclusion of students with special needs into its programming.

During the 2017-2018 school year, more than three million students aged 12-21, i.e., the estimated age range of most students enrolled in SBAE, were served under the Individuals with Disabilities Education Act (IDEA) (Office of Special Education and Rehabilitative Services, 2019). According to the National Association of Agricultural Educators (2019), nearly one million students are enrolled in SBAE programs nationwide. In addition, the National Center for Education Statistics (2019) reported that in 2008, more than $18 \%$ of the nation's Career and Technical Education (CTE) enrollees identified as special needs students, which supports the approximation of about 180,000 of such students are enrolled year-over-year in SBAE. Although the inclusion of students with special needs in SBAE is a norm today, a historical account of their inclusion provides insight and context for SBAE teachers, guidance counselors, and other school officials. By reviewing the storied past of this phenomenon it is possible to understand better the importance of inclusion and how to meet the needs of such students. 


\section{Purpose and Research Questions}

"All students, including those with learning disabilities, are entitled to the best instruction that agricultural education teachers can provide" (Faulkner \& Baggett, 2010, p. 94). The primary purpose of this historical study was to describe forces presaging the inclusion of students with special needs in SBAE, and how such was achieved over time, as reported in The Agricultural Education Magazine and in the Journal of Agricultural Education. This study also examined how agricultural education teachers served the learning needs of students with special needs over time. Two questions guided the study: (1) What major federal legislation addressed the educational needs of students with special needs in U.S. public schools? and (2) How did SBAE respond over time to the need to educate students with special needs? Historical research methods were used to achieve the study's purpose and answer its questions (McDowell, 2002).

\section{Method}

"The purpose of historical research is to make sense of a series of events in a specified timeframe, establish their authenticity, understand the connection between them and interpret their wider significance" (McDowell, 2002, p. 26). This form of research includes identifying an area of study, forming guiding questions, collecting, organizing, verifying, validating, analyzing and selecting data, answering the questions, and compiling the research report (Cohen \& Manion, 1994; McDowell, 2002). Historical research demands a "systematic gathering and criticism of documents, records, and artifacts to provide a description and interpretation of past events or persons" (McMillan, 2012, p. 15). Moreover, "[t]he historical study of an educational idea or institution can do much to help us understand how our present educational system has come about" (Cohen \& Manion, 1994, p. 46). Historical research seeks to find causal explanations and provide a meaningful account of past events that changed our society and culture (McDowell, 2002). Moreover, a systematic organization of historical data allows for better explanation of past phenomena by stitching together ideas, events, actors, and memories that would otherwise be fragmented if studied alone or without examining the larger context (McDowell, 2002). As such, the intent of this historical research was to connect past events to current themes and issues in agricultural education, including how educational programs in agriculture have continually evolved to meet the needs and interests of students (Roberts, Harder, \& Brashears, 2016).

Using Internet search engines and the Oklahoma State University library's search tools, primary and secondary sources, including books, government reports, and articles from peer-refereed journals and The Agricultural Education Magazine, were reviewed to provide the study's data. The study's key search terms included: handicapped, mental retardation, special education in agricultural education, special education in vocational education, special education laws, special needs, and students with special needs.

Resources outside of the agricultural education discipline provided the foundational data for answering the first research question, whereas The Agricultural Education Magazine and the Journal of Agricultural Education were sourced to address the second 
Journal of Research in Technical Careers

research question. Data for research question one were collected and analyzed chronologically, as derived from peer-refereed journals, books, and government reports. The data collection for research question two began by reviewing The Agricultural Education Magazine online database for articles addressing the inclusion of students with special needs. It was revealed that eight issues of the magazine had featured the learning experiences of students with special needs spanning over 45 years and throughout six different decades (1968 to 2012). These issues contained 63 articles written by 87 authors. As Enns and Martin asserted (2015), the number and wide variety of authors makes the magazine an important body of historical evidence representative of the profession and therefore the phenomenon studied (McDowell, 2002). In this case, the authors' shared experiences that reflected their profession's views on the inclusion of students with special needs in SBAE over time. Manuscripts from the Journal of Agricultural Education that addressed issues related to meeting the learning needs of special education students in SBAE were obtained from the online database. These and related acts of sourcing addressed Wineburg's second heuristic, i.e., to identify " "the source or attribution of the document" (as cited in Johnson \& Christensen, 2014). A third heuristic of historical research, as attributed to Wineburg by Johnson and Christensen (2014), is contextualization, or the chronology of key events especially the passage of federal legislation. Contextualization was central to answering research question one, as summarized in Tables 1 and 2.

The data were collected thematically, e.g., facilities and related needs, instructional practices and variability, SAEs, teacher preparation, among other attributes, then chronologically analyzed and compared (McDowell, 2002). Sources were subjected to both internal and external criticism to determine accuracy and authenticity, respectively. Selected findings were triangulated to establish sufficient corroboration as an exercise of negative criticism, and further support the study's credibility (Johnson \& Christensen, 2014; McDowell, 2002). As one construct compromising the researchers' internal criticism of the study's sources, i.e., positive criticism, we discussed and refined our collective understanding and interpretations, as needed (Johnson \& Christensen, 2014). The focus of The Agricultural Education Magazine is for its authors to draw from and share their personal experiences as educators - mainly regarding teaching SBAE or preparing teachers for such - which supported the authenticity and credibility of using their writings as historical evidence. The stating of authors' professional titles as part of the articles' presentations in the magazine revealed this authentication and established them as credible sources regarding the phenomenon studied. The Journal of Agricultural Education and its predecessor is a longstanding peer-refereed venue for publishing research involving SBAE, including topics related to the inclusion of students with special needs.

\section{Findings}

Research Question 1: What major federal legislation addressed the educational needs of students with special needs in U.S. public schools? The differential treatment of individuals with disabilities can be traced to ancient times when the Romans kept people with disabilities as jesters for royalty (Karten, 2008). Centuries later, at a time 
Table 1. Select Federal Legislation Mandating Aspects of Special Education Prior to 1975

Federal Legislation

Captioned Files Acts of 1958 (P.L.

$85-905)$

Act of 1959 (P.L. 86-158)

Teachers of the Deaf Act of 1961

(P.L. 87-276)

Elementary and Secondary

Education Act ${ }^{\mathrm{a}}$ (ESEA; P.L. 8910)
Training of Professional Personnel Description of Legislation

Supported the production and distribution of accessible films for individuals who were deaf or hard of hearing (USDOE, 2010)

Helped train program administrators and teachers of children with mental retardation (USDOE, 2010)

Trained instructional personnel for children who were deaf or hard of hearing (USDOE, 2010)

Provided states with direct grant money to assist with educational purposes; the act included the 1966 amendment creating the Bureau of Education for the Handicapped in the Department of Health, Education, and Welfare that later became the Office of Special Education Programs (Katsiyannis et al., 2001)

Vocational Education Act of $1963^{\mathrm{b}}$ Required specific programs for students with special needs, i.e., academic, (P.L. 88-210) socio-economic, or other handicaps (Faulkner, 1968)

State Schools Act ${ }^{\mathfrak{c}}$ (P.L. 89-313) Extended the benefits of ESEA to children in state programs (USDOE, 2010)

Education of the Handicapped Act Further extended federal grant programs of ESEA and included grants to of 1970 (P.L. 91-230) disabilities; act was the basis for Public Law 94-142 (Katsiyannis et al., 2001)

Note. ${ }^{\text {aE}}$ Elementary and Secondary Education Act enacted in $1965 .{ }^{\mathrm{b}} \mathrm{SBAE}$, known then as vocational agriculture education, was affected by this act. 'State Schools Act enacted in 1965.

when Nazi Germany euthanized individuals with disabilities, the U.S. workforce saw a flood of adults with disabilities filling vacancies left by those who fought in World War II (Karten, 2008). Evidence supporting the inclusion of students with special needs began to accumulate after the war time workforce integration of such individuals (Karten, 2008). The Civil Rights movement of the 1950s and 1960s also inspired the parents of children with disabilities to advocate for appropriate educational opportunities that matched their children's unique learning needs (Karten, 2008; Katsiyannis, Yell, \& Bradley, 2001). This need to provide appropriate learning opportunities for students with disabilities is what led the U.S. Congress to pass the Education for All Handicapped Children Act (EAHCA) in 1975 (Karten, 2008; Katsiyannis et al., 2001; U.S. Department of Education [USDOE], 2010). Even though EAHCA was the watershed moment of the movement to include all students in a free and appropriate education, earlier federal legislation (see Table 1) had also supported improved programs and services for individuals with special learning needs (USDOE, 2010).

The federal government provided support for training special education teachers and related specialists, and reached more than 30,000 special education professionals by 1968 (Katsiyannis et al., 2001). However, even with the specialized training for special education teachers prior to 1975 , more than three million students with disabilities enrolled 
in schools were not receiving an education deemed appropriate to their needs with more than 1.75 million students with disabilities not receiving any education services during that time (Katsiyannis et al., 2001). As of 1970, "U.S. schools educated only one in five children with disabilities, and many states had laws excluding certain students from school, including children who were deaf, blind, emotionally disturbed, or mentally retarded" (USDOE, 2010, p. 3). In addition, nearly 200,000 people, with significant disabilities, were housed within restrictive state institutions and "received care for basic needs rather than education and rehabilitation" (USDOE, 2010, p. 3).

To address the need for significant educational reform regarding students with disabilities, the EAHCA was created by Congress as an amendment to the 1970 Education of the Handicapped Act. Congress proposed the amendment "to ensure that each student with a disability received an education suited to his or her unique needs" (Katsiyannis et al., 2001, p. 326). EAHCA, also referred to as Public Law 94-142, guaranteed a free appropriate public education to each child with a disability and provided states and local education agencies, i.e., school systems or school districts, with financial incentives to comply with the law (USDOE, 2010). The primary purposes of Public Law 94-142 include:

[a] to assure that all children with disabilities have available to them . . . a free appropriate public education which emphasizes special education and related services designed to meet their unique needs, [b] to assure that the rights of children with disabilities and their parents ... are protected, [c] to assist States and localities to provide for the education of all children with disabilities, and [d] to assess and assure the effectiveness of efforts to educate all children with disabilities. (USDOE, 2010 , p. 5)

After 1975, classrooms became more inclusive of students with special needs and "the futures of children with disabilities [were] brighter" (USDOE, 2010, p. 11). As a result, in $2010,57 \%$ of students with disabilities were learning in general education classrooms for at least $80 \%$ of the school day (USDOE, 2010), i.e., the concept of mainstreaming was at work. Hudson, Graham, and Warner (1979) explained that students "labeled as handicapped must receive their education within the mainstream [emphasis added] of the regular school environment" (p. 58). Moreover, Blanton, Pugach, and Florian (2011) reported the number of students spending $80 \%$ of the school day in general education had increased compared to the previous decade. The EAHCA has been amended numerous times since its passage in 1975 to expand the rights of students with disabilities, including a change to the name of the law: The Individuals with Disabilities Education Act of 1990 (Katsiyannis et al., 2001). Table 2 shows the major amendments made after EAHCA became law in 1975. The IDEA Amendments of 1997 established "the right of students with disabilities to a free appropriate public education, including special education, related services, and transition services" (Wonacott, 2001, p. 2). IDEA mandated the implementation of an Individualized Education Program (IEP) (Wonacott, 2001). An IEP provides direction for a student's educational goals by identifying "the student's current level of educational performance; measurable goals and objectives; special education, related services, and other accommodations to be provided; and the extent of participation with nondisabled students" (Wonacott, 2001, p. 2). In addition, an IEP specifies 
Table 2. Major Amendments to the EAHCA ${ }^{\mathrm{a}}$

The Individuals with Disabilities Education Act of 1990; P.L. 101-476

The Individuals with Disabilities Education Act Amendments of 1997; P.L. $105-17$
- $\quad$ Changed the name of the law from the EAHCA ${ }^{\mathrm{a}}$ to the IDEA ${ }^{\mathrm{b}}$

- $\quad$ Added autism and traumatic brain injury as categories of disabilities
- $\quad$ Strengthened the role of parents

- $\quad$ Emphasized student progress toward meaningful educational goals

- Encouraged resolution of differences by using non-adversarial mediation

- $\quad$ Made changes to the IEP team and document

- Added disciplinary provisions to the IDEA


1975; ' Individuals with Disabilities Education Act

modifications to be made for the student, and how educational progress will be measured and shared with parents (Wonacott, 2001).

Eisenman (2000) suggested all students, including those with disabilities, should participate in programs that infuse academic curriculum with career-related learning experiences. Students involved in CTE, including SBAE, have higher academic achievement and increased postsecondary engagement (Eisenman, 2000). Under the IDEA of 1990, CTE programs must provide free appropriate education to students identified as having disabilities and in need of special education and related services, i.e., physical and occupational therapy, counseling, transportation, to optimize their opportunities to benefit from the programs in which they may enroll (Dieterich \& Smith, 2015). In 2008, Congress reauthorized the Higher Education Opportunity Act, adding more provisions for the preparation of general education teachers to instruct students with special needs (Blanton et al., 2011). This reauthorization mandated states receiving funding to report the "extent to which teacher preparation programs prepare teachers" to serve this population (Higher Education Opportunity Act, 2008a, p. 3135). In addition, the act required higher education institutions' teacher preparation programs to provide assurance of training for mainstream teachers regarding the "instruction to diverse populations, including children with disabilities" (Higher Education Opportunity Act, 2008b, p. 3152).

Although inclusion of special needs students is mandated by law, teacher preparation for the instruction of these students in the United States is only influenced by federal policies and programs, i.e., no comprehensive mandate or nationwide policy related to teacher preparation exists (Blanton et al., 2011). Individual states, however, have increased standards for teacher licensing which influence their teacher preparation standards, and systematically includes individualized learning for special needs students (Darling-Hammond, 2005). As part of traditional teacher preparation in some states, programs for preservice agricultural educators include curriculum to better prepare these future teachers to serve students with special needs in SBAE (Giffing, Warnick, Tarpley, \& Williams, 2010). 
Research Question 2: How did SBAE respond over time to the need to educate students with special needs? With the mandates put in place by the enactment of federal legislation (see Tables $1 \& 2$ ), students with special needs have been accommodated in U.S. Public Schools, including SBAE programs. It might seem as though this always has been the case, but IDEA "shifted the focus of vocational education to serving special populations" (Moore, 2004, p. 5). SBAE teachers are legally responsible to accommodate their programs for students with special needs (Daniels \& Walker, 1975; Filson \& Whittington, 2011). Moreover, "[t]he unique strengths of agricultural education are what make it a successful learning strategy for regular and exceptional students alike" (Osborne, 1993, p. 3). CTE, including SBAE, emphasizes a hands-on approach in its instruction and has provided opportunities for special needs students to flourish (Gaona, 2004). In his 1975 article in The Agricultural Education Magazine, Walls (1975) stated: "Teaching the disadvantaged and handicapped may well be one of the greatest satisfactions a teacher can receive during [their] teaching career, especially if [they have] a genuine interest in helping those less fortunate" (p. 263). However, Toole and Eddowes (1985) may have best described the capacity of SBAE: "With its emphasis on learning by doing, its use of scientific innovation and technology and its appreciation of the needs and interests of individual students, vocational agriculture seems uniquely suited to help handicapped students succeed" (p. 13).

Vocational education for special needs students through SBAE. Before implementation of the EAHCA in 1975, the Vocational Education Act of 1963 was the basis for requiring that SBAE be made available to students with special needs (Walls, 1975). The act "charged vocational education with the responsibility of providing special programs for persons who have academic, socio-economic, or other handicaps that prevent them from succeeding in the regular vocational education programs" (Faulkner, 1968, p. 57). EAHCA broadened the scope of students to be served (Hamlin, 1965) and required that states devote $25 \%$ of their federal funding to provide educational opportunities for handicapped and disadvantaged students (Walls, 1975).

J. B. Hamilton (1968) asserted that "[s]erving the educational needs of rural youth with special needs is a problem of considerable magnitude" (p. 74). However, without a clear federal definition of students with special needs, state funding agencies forced the issue of "identifying handicapped and disadvantaged students in a consistent and accurate manner" (O'Reilly, 1975, p. 36). The Vocational Education Act of 1963 encouraged educational programs at the state and local levels to develop plans to meet the needs of special groups, but no clear definition existed regarding which individuals made up specific special groups (O'Reilly, 1975). It was during the 1960s that SBAE professionals began addressing concerns and practices for students with special needs in The Agricultural Education Magazine, including several themed issues that addressed the topic during five different decades (see Table 3). Even though SBAE had always emphasized hands-on learning, which tended to benefit many students with disabilities, the programs were not specifically designed to address their unique learning requirements (Walls, 1975), and the profession needed guidance. 
Table 3. Special Needs-Themed Issues of The Agricultural Education Magazine following Enactment of Vocatj Education Act of 1963

\begin{tabular}{llrr}
\hline Issue Date & Theme Title & Articles $^{\mathrm{a}}$ & Authors $^{\mathrm{b}}$ \\
\hline September 1968 & Agricultural Education for Persons with Special Needs & 8 & 10 \\
April 1971 & Agricultural Education for the Disadvantaged & 12 & 14 \\
May 1975 & Teaching the Disadvantaged and Handicapped & 8 & 10 \\
November 1980 & Programs for Exceptional Students & 9 & 11 \\
February 1985 & Vocational Agriculture and the Handicapped Student & 6 & 9 \\
March 1993 & Serving Individuals with Disabilities & 7 & 12 \\
December 1993 & Teaching Academically Disadvantaged Students & 5 & 6 \\
May/June 2012 & Serving Students in Agricultural Education with Special Needs & 8 & 15 \\
& & & 63 \\
\hline
\end{tabular}

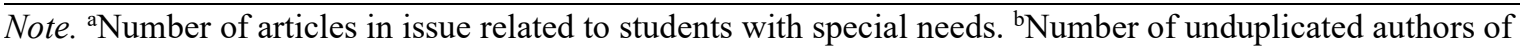
special education-themed articles by issue.

September 1968 was the first of several issues of The Agricultural Education Magazine that would highlight the inclusion of students with special needs in SBAE (see Table 3). In this third issue of 1968, Editor J. Robert Warmbrod stated: "Agricultural educators in general, and high school teachers specifically, can rightfully be proud of the emphasis given to the individual needs, characteristics, and interests of students in planning and conducting instructional programs in agriculture" (p. 55). Multiple articles in the issue elaborated on Warmbrod's position. For example, Harlan and Grimes (1968) explained how the Coordinated Shop Program within their department at Rogers High School in Arkansas provided opportunities for "students who are mentally and academically slow to participate with students of their own peer group" (p. 58). In recognition of the language used at that time, the pupils identified as students with special needs in this issue of the magazine were described as slow learners, poor performing students, pupils with poor educational backgrounds, and potential dropouts (Faulkner, 1968; Walker, 1968). Students with "emotional and psychological problems which are not serious enough to require constant attention or institutionalization" were referred to as students with special needs (Faulkner, 1968, p. 57). The article "Identifying the Educationally Handicapped" described such students as having "an obvious lack in the basic skills" (Hamilton, D. A., 1968, p. 66).

D. A. Hamilton (1968) explained: "Students who upon investigation or observation portray evidence of being educationally handicapped cannot be expected to survive educationally, nor to become viable components of the society of which they are a segment unless special help is given to them" (p. 66). He continued: "The student who does not achieve is labeled as 'slow' or of 'low intelligence.' . . . intelligence is not only the determining factor. Students of average, above average, or below average intelligence may be educationally handicapped" (p. 66). This initial outreach by the magazine to teachers of agriculture about serving students with special needs also included programs for the mentally retarded (Hamilton, D. A., 1968). For instance, Edward Ortiz's (1968) article spotlighted a New York agricultural education program working with mentally retarded students by focusing on greenhouse and nursery production. In addition, J. B. Hamilton 
Journal of Research in Technical Careers

(1968) recognized that many youths with special needs often lacked communication and social skills, i.e., learning outcomes for which vocational agriculture education, and its FFA component, had been designed to help students achieve. J. B. Hamilton (1968) pushed for reform and said: "[Teachers] must be prepared and willing to work with the less able student and with the socio-economically deprived" (p. 75).

The 1968 Amendment to the Vocational Education Act of 1963 solidified the need for students to remain in regular education programs, if they could benefit from the instruction (Lee, 1971). The 1971 issue of The Agricultural Education Magazine highlighted many programs set to include and help students with special needs. Dawson (1971) stated that although past generations pushed aside and isolated disadvantaged members of society, "to neglect educating and training the disadvantaged portion of our society is a waste of human resource[s] which is detrimental to the welfare of our nation" (p. 242). Moreover, Lee (1971) emphasized the importance of including students with disabilities in regular education classes to prevent isolation from their non-disabled peers and to prevent them being labeled as inferior students. The Education Amendment of 1976 defined the scope and different conditions of students with special needs, and it placed a portion of federal vocational funding aside for special needs populations (Scanlon \& Baggett, 1985). However, even with this federal funding, and later the Carl D. Perkins Act of 1984, which called for an allocation of funds to be spent on special populations (Moore, 2004), it was still questioned whether teachers of vocational education could adequately serve special needs students without proper training (Scanlon \& Baggett, 1985). "What these young people need in order to become responsible adults are persons that will help them find their talent and abilities and develop them" (Downey, 1985, p. 5), including teachers of agriculture through their SBAE programs.

The Agricultural Education Magazine highlighted numerous programs (Downey, 1985; Good-Hamilton, 1985; Toole \& Eddowes, 1985; Tyrrell, 1985) which provided opportunities for students with special needs to flourish through modified curriculum and hands-on learning experiences following enactment of the Carl D. Perkins Act of 1984. Good-Hamilton (1985) implemented goal-oriented experiences within a horticulture program that emphasized hands-on learning approaches, including leadership and managerial skills. Moreover, some vocational agriculture teachers received disability awareness training through in-service opportunities to help understand better the needs of their students (Toole \& Eddowes, 1985). Tyrell wrote of the need for career awareness and that opportunities be made available to all students, and such were of primary importance to not only regular education students, but also special education students. Tyrell attributed the successful inclusion of all students to the "educational tone of the program" (p. 17). Cooper, Bocksnick, and Frick (2002) explained: "While slight modification of an activity might be required, it should resemble the activity of mainstream students. Students should never feel that they are being held separate because of their disability" (p. 6).

SBAE teachers were also responsible for accommodating the physically handicapped, such as wheelchair-bound students, including the provision of ramp access to agricultural mechanics facilities and other laboratories, and adapting power equipment to safely accommodate students with disabilities (Bruwelheide, 1985; Daniels \& Walker, 1975). Specifically, Bruwelheide (1985) stated: "when accommodation of the physically 
handicapped student into a vocational agriculture program is successful, education and career building experiences are possible" (p. 13). Delks and Sillery (1993) stressed the need for teachers to ensure appropriate facilities and transportation for students with special needs when planning activities outside of the classroom, such as their participation in field trips.

The 1970s saw an emphasis on providing vocational education for students with disabilities increase the likelihood of them entering the workforce (Curtis, 1975; Steed, 1971). In the early 1970s, vocational agriculture teachers in Mississippi developed programs for students with special needs to acquire the skills needed to take on blue-collar jobs that required agricultural mechanics competencies, which filled a void left by the shift toward white-collar jobs by other program graduates (Steed, 1971). As a result, more disadvantaged or handicapped youth gained employment skills through vocational agriculture education, thus reducing their likelihood of unemployment (Curtis, 1975).

In 1988, the Future Farmers of America changed its name to the National FFA Organization to appear more inclusive to students who were not interested in pursuing traditional, production-oriented aspects of agriculture such as farming and ranching (National FFA Organization, 2018b). At that time, the organization also changed its insignia from Vocational Agriculture to Agricultural Education (National FFA Organization, 2018a). The response from agricultural educators regarding the inclusion of students with special needs during this transition continued to be positive, including another themed issue of the magazine in 1993. After 1993 it was nearly two decades (see Table 3) before The Agricultural Education Magazine had another issue themed to highlight the teaching of special needs students. However, articles did appear during this period that positively addressed the topic and described the creation of curriculum for the inclusion of special needs students (Cooper et al., 2002; Filson \& Whittington, 2011; Moffitt, 2004; Moore, 2004).

Instructional variability, including hands-on learning experiences. Variability in the agricultural education classroom provides opportunities for students with special needs to be involved in hands-on, enriching course content (Easterly \& Myers, 2011; Giffing et al., 2010; Pavelock \& Harlin, 2013). “Agricultural education's variety of teaching methods, authentic instruction, active student response, and hands-on approach have the potential to benefit students with disabilities" (Giffing et al., 2010, p. 112). Stair, Moore, Wilson, Croom, and Jayaratne (2010) asked SBAE teachers to rate the use and effectiveness of recommended practices applied to special needs students and found the most effective strategy emphasized hands-on learning and skills development. Smith and Rayfield (2019) examined the influence of sequencing instruction for students with disabilities in the SBAE classroom and concluded that "students with learning disabilities likely benefit from enrollment in an agricultural education course that focuses on providing concrete experiences for grasping abstract concepts" (p. 231).

Pavelock and Harlin (2013) asserted that "[f]or special needs students, agricultural science classes are an opportunity to learn valuable career skills outside of traditional classroom settings" (p. 6). In support, Johnson, Wilson, Flowers, and Croom (2012) found $87 \%$ of teachers in their study agreed that participating in an SAE "help[ed] students with special needs set career goals" (p. 46). Students' learning not only becomes more proficient 
when they are active in the learning process, but also when their ability levels are matched with appropriate individualized instruction (Easterly \& Myers, 2011). In an article describing an SAE program targeting special needs students, Farmer (1993) stated: "Research has found that handicapped and disadvantaged students respond effectively and immediately to proven methods of hands-on teaching" (p. 15). Moreover, allowing special needs students to take part in inquiry-based learning experiences is beneficial by creating opportunities for them to "take charge of their own learning" (Phillips \& Myers 2012, p. $10)$.

The inclusion of students with special needs can benefit other students enrolled in SBAE if teachers are committed to instructional practices that invite all students to participate, especially by teaching through real-life examples (Curtis, 1975; Giffing \& Warnick, 2012). Phillips and Myers (2012) explained: "By providing opportunities for hands-on and active learning . . . teachers can serve a wide range of students who may benefit from agricultural education programs" (p. 10). Giffing and Warnick (2012) also stressed that students, including those with special learning needs, learn valuable life lessons in SBAE. To this point, Osborne (1993) asserted: "Experience has shown that academically disadvantaged students often perform better in agriculture classes than in other school subjects" (p. 3).

In addition to classroom and laboratory learning experiences, SAEs allow students with special needs to flourish by providing opportunities to learn through hands-on approaches customized to their unique interests and abilities (Cooper et al., 2002; Moffitt, 2004). Such activities in SBAEs can foster positive and satisfying learning experiences for students with disabilities (Farmer, 1993; Giffing et al., 2010; Woehler, 1975). For instance, teaching students "how to water plants, the proper tools to use in a greenhouse and the importance of cleaning up a work area can all be valuable career skills that they may not learn in any other course at school" (Pavelock \& Harlin, 2013, p. 6).

Johnson et al. (2012) measured teacher perceptions of students with special needs in SAE and FFA activities. They reported more than $94 \%$ of teachers agreed with the statement, "SAE is beneficial to students with special needs" (p. 46), and nearly $90 \%$ of the study's respondents agreed that an SAE "enhances the social skills of students with special needs" (Johnson et al., 2012, p. 46). Cooper et al. (2002) further concluded it was not only the modifications enabling the success of special needs students, but rather "the support and positive influence that a fully integrated agricultural education program can provide" (p. 7).

Another example, The Special Lamb Adoption Program, began in 1989 with the aim of including students with special needs in a market lamb SAE in Georgia (Farmer, 1993). The program paired a mentor and a special needs student to jointly care for and exhibit the animal at local and area junior livestock shows (Farmer, 1993). The program inspired similar approaches throughout the nation, including other livestock species, and is a positive example of "how the social, intellectual, and physical needs of handicapped students can be met for the benefit of all" (Farmer, 1993, p. 15).

Preparation of SBAE teachers to serve the needs of special education students. Faulkner and Baggett (2010) reported that $73 \%$ of the teacher education programs in their study preparing SBAE teachers required a special education course as part of the curricula. 
Other researchers (Aschenbrener, Garton, \& Ross, 2010; Elbert \& Baggett, 2003; Faulkner \& Baggett, 2010; Giffing et al., 2010; Kessell, Wingenbach, \& Lawver, 2009; Mallilo, Baggett, \& Curtis, 1983) studied teacher readiness to instruct students with disabilities. In 2010, Giffing et al. assessed the perceptions of Idaho agriculture teachers as related to the inclusion of students with special needs. Their findings indicated the teachers "had the will to include the majority of students with specific disabilities yet lacked the skill to do so successfully" (Giffing et al., 2010, p. 110), and that "the most pressing concern with all students is safety" (p. 111).

Dormody, Seevers, Andreasen, and VanLeeuwen (2006) concluded that "agricultural education teachers can expect to work with students with all of the types of special needs, and, hence, need to receive pre-service and in-service training on including these students in all aspects of the program" (p. 102). In addition, Giffing et al. (2010) and Mack and Luft (1981) recommended further training, including in-service programs and professional development, to address the needs of students with specific disabilities in agricultural classroom and laboratory settings. Moreover, prospective teachers must be prepared to instruct students with disabilities regardless of the route to licensure because "96\% of students with disabilities spend at least part of their day in general education classes" (Blanton et al., 2011, p. 7). This would involve courses taught by teachers without special education credentials, including most instructors of SBAE. Although traditionally certified teachers of agriculture earn a specialized credential, they are still considered general education instructors regarding special education students (Blanton et al., 2011). As such, SBAE instructors can serve as the general education teacher of record on a student's IEP, which describes the services and support provided to help special needs students meet individualized learning goals (Blanton et al., 2011).

To supplement general education teacher credentialing, including individuals credentialed to teach agriculture, the U.S. Office of Special Education Programs funded specialized grants to include special education content in the general teacher education curriculum (Blanton et al., 2011). This funding, which began as early as 1975, "created momentum for preparing general educators to teach students with disabilities and represented an important initial strategy to ensure that general education teachers had the knowledge, skills, and attitudes necessary" to effectively teach special needs students (Blanton et al., 2011, p. 20). However, the grants reinforced the belief that general education teachers must take a specific and required course in special education because "students with disabilities are so different from their peers that a general education teacher is not qualified to teach them" (Blanton et al., 2011, p. 20). Newly redesigned programs, which more closely matched the ideals and requirements of IDEA and Elementary and Secondary Education Act (ESEA), were introduced in 2007 to help general education teachers become highly qualified and "better equipped to meet the needs of students with disabilities" (Blanton et al., 2011, p. 20).

Crunkilton (1985) stated agricultural education preservice teachers "need to be familiar with the federal, state, and local agencies that can lend assistance when working with the handicapped" (p. 21). Hinders (1995) opined that it was the responsibility of universities to "take an active role in preparing teachers to be competent in meeting the needs of special education students in the general education setting" (p. 206). In support, 
Journal of Research in Technical Careers

Blanton et al. (2011) concluded that to improve the learning outcomes of students with special needs, we must invest more in the preparation of general education teachers. He echoed the views of J. B. Hamilton (1968), who said that SBAE teachers "must be prepared to work with the less able student" (p. 75).

Concerns regarding the Inclusion of Special Needs Students in SBAE. Although most of the literature reviewed indicate the positive aspects and prospects for special education students enrolling in SBAE, criticisms of inclusion were also articulated over time. Some criticism came from the paucity of teacher preparation for special populations as well as a deficit in the professional support needed to properly accommodate students with special needs (Bruwelheide, 1985; Mallilo, Baggett, \& Curtis, 1983). For instance, Bobbitt (1975) concluded: "Those who need training the most should receive top priority and be sought out and assisted if vocational education in agriculture is to meet the true needs of our society" (p. 255). Mallilo et al. (1983) identified curriculum modification and lack of teacher training as two of the top problems in mainstreaming students with special needs into the SBAE classroom.

Moreover, Faulkner (1968) opined that those individuals with severe handicaps who required high levels of intervention should "not [be] included among the groups vocational education should be serving" (p. 59). Bobbitt (1975) and Croom and Moore (2004) addressed fears of SBAE becoming a dumping ground for students unable to succeed in other courses. On the other hand, Bobbitt (1975) also recognized that an opportunity existed to help students who needed the most training, and he challenged vocational agriculture education to "openly recruit disadvantaged and handicapped students who have an interest in agriculture" (p. 255). Further, Filson and Whittington (2011) asserted that "the inclusion of learners with special needs is not only mandated by law, but is a civic and moral duty for secondary agriculture teachers" (p. 10).

To remain relevant in U.S. Public Schools, SBAE teachers must be well prepared and know how to effectively embrace and teach all students. Or, as Curtis (1975) opined: "Educators must make it happen. The unique history of vocational agriculture and its concern for students makes it appropriate that agriculture lead the way" (p. 243) regarding the inclusion of all students, whether special needs or not. Cooper et al. (2002) succinctly expressed the importance of supporting students with special needs in SBAE: "Many of these special needs students have simply never heard, 'You can do it'” (p. 7).

\section{Conclusions}

At the time of the EAHCA's enactment, Woehler (1975) stated: "there is no question that the various components of the agricultural education umbrella will continue [emphasis added] to play a significant role in teaching the disadvantaged and handicapped" (p. 246). SBAE had served students with special needs prior to the EAHCA (Faulkner, 1968; Grimes \& Harlin, 1968; Hamilton, J. B., 1968; Hamlin, 1965; Warmbrod, 1968), but the requirement to do such was further solidified by federal statute in 1975. Through key federal legislation, especially the EAHCA of 1975, students with special needs were launched into mainstream education (Karten, 2008; Katsiyannis et al., 2001). Although preceded by other legislation to benefit individuals with special needs (see Table 1), this 
act was the driving force for mainstreaming these students into normal or regular classrooms (Hudson et al., 1979), including their enrollment in SBAE.

SBAE has provided a special learning space for students with disabilities by providing hands-on learning experiences (Easterly \& Myers, 2011; Gaona, 2004; Giffing et al., 2010; Pavelock \& Harlin, 2013; Phillips \& Myers, 2012). Moreover, it offered an overall positive response to the inclusion of students with special needs following implementation of EAHCA, including the promotion of unique programs in which to involve them (Armbruster, 2012; De Lay \& Burden, 2012; Downey, 1985; Farmer, 1993; Filson \& Whittington, 2011; Good-Hamilton, 1985; Toole \& Eddowes, 1985; Tyrrell, 1985). These efforts were highlighted in eight issues with related themes, including 63 articles authored by 87 educators, and published over 45 years and six different decades in The Agricultural Education Magazine (see Table 3). Teacher educators also provided some focus on the preparation of teachers to properly instruct students with special learning needs, as described in articles published in the Journal of Agricultural Education (Andreasen, Seevers, Dormody, \& Vanleeuwen, 2007; Aschenbrener et al., 2010; Dormody et al., 2006; Elbert \& Baggett, 2003; Faulkner \& Baggett, 2010; Giffing et al., 2010; Kessell et al., 2009). To this point, Faulkner and Baggett (2010) stated: "techniques that increase student learning, especially those with learning disabilities, are expected [emphasis added] to be used in secondary agricultural education programs" (p. 88). Moreover, "all students, including those with learning disabilities, are entitled to the best instruction that agricultural education can provide" (Faulkner \& Baggett, 2010, p. 94).

\section{Discussion, Implications, and Recommendations}

More remains to be done for students with special needs who enroll in SBAE and choose to participate in and benefit from the many learning experiences it offers. Whether through general instruction, or that intended to serve students with special learning needs, Hinders (1995) admonished: "The education field cannot expect teachers to be comfortable and skilled at addressing varying ability levels in the regular education classroom without experience and training" (p. 206). Therefore, continuing to provide related teacher preparation and in-service professional development is essential. However, a "limited amount of research exists on which modifications and [teaching] methods work best in the SBAE classroom" (Easterly \& Myers, 2011, p. 37). Opportunities for inclusion and modifications for special needs students have been studied, especially regarding the instruction and SAE components of SBAE's three-circle model. However, additional research should be conducted on the effects of SBAE's leadership development component, FFA, to achieve "the ultimate goal of personal growth and practical learning for all students" (Easterly \& Myers, 2011, p. 44). This also warrants more investigation regarding the proper training of teachers and advisors in serving students with special needs.

Our review of existing literature exposed a dearth of findings regarding special needs SBAE parental views concerning how the program's three-circle model for learning could best meet their children's interests and abilities. In addition, research designed to identify and then promulgate the use of best practices when teaching and advising students 
with special needs would be another important contribution toward meeting stakeholders'

resource needs. Further research also should be done to assess the number of students with special needs enrolled in SBAE and their level of involvement in the classroom, as well as within the FFA and SAE components of its three-circle model. Further, studies to determine the effects of SBAE on students with special needs and on those without who share these experiences could provide important insights for the profession. These shortcomings and future research challenges notwithstanding, this study informs the CTE literature about how SBAE sought to serve students with special needs over many decades and situated its efforts in the context of numerous federal statutes, initiatives, and priorities presaging such. Current and future teachers, local, state, and national administrators, as well as education policymakers at all levels, may benefit from this contribution to the literature.

The enactment of key legislation to assure the inclusion of students with special needs into mainstream classrooms afforded productive, valuable experiences to those who enrolled in SBAE during the last six decades. With the opportunity to enroll in SBAE and participate in FFA, the young man back in the show barns at his county fair was exposed to a program that embraced students with special needs and helped them to excel in concert with their interests, needs, and abilities. His experiences may have also had a lasting impact on his teacher and fellow classmates, which is another area ripe for research regarding the effects of special needs students on others with whom they interact in SBAE programs. Only time will tell what the future holds, and the impact that SBAE will have on tomorrow's students with special needs, their communities, and our society overall.

\section{References}

Andreasen, R. J., Seevers, B. S., Dormody, T. J., \& Vanleeuwen, D. M. (2007). Training needs of New Mexico agricultural education teachers related to inclusion of students with special needs. Journal of Agricultural Education, 48(4), 117-129. https://doi.org/10.5032/jae.2007.04117

Armbruster, J. (2012). Opportunities for members with special needs National FFA Organization. The Agricultural Education Magazine, 84(6), 21-23. Retrieved from https://www.naae.org/profdevelopment/magazine/archive_issues/Volume84/2012_0506.pdf

Aschenbrener, M. S., Garton, B. L., \& Ross, A. L. (2010). Early career agriculture teachers' efficacy toward teaching students with special needs. Journal of Agricultural Education, 51(4), 105-117. https://doi.org/10.5032/jae.2010.04105

Blanton, L. P., Pugach, M. C., \& Florian, L. (2011). Preparing general education teachers to improve outcomes for students with disabilities. (Policy Brief). American Association of Colleges for Teacher Education. Retrieved from https://www.ncld.org/wp-content/uploads/2014/11/aacte_ncld_recommendation.pdf

Bobbitt, F. (1975). Mainstreaming disadvantaged and handicapped students. The Agricultural Education Magazine, 47(11), 250, 255. Retrieved from https://www.naae.org/ profdevelopment/magazine/archive_issues/Volume47/v47i11.pdf

Bruwelheide, K. (1985). Adapting equipment for the handicapped. The Agricultural Education Magazine, 57(8), 13-15. Retrieved from https://www.naae.org/profdevelopment/magazine/archive_issues/Volume57/v57i8.pdf 
Cano, J., \& Moore, E. A. (2010). Preparing teachers for diverse audiences. In R. M. Torres, T. Kitchel, \& A. L. Ball (Eds.), Preparing and advancing teachers of agricultural education (pp. 257-267). Columbus: The Ohio State University, Curriculum Materials Service.

Cohen, L., \& Manion, L. (1994). Research methods in education (4th ed.). New York: NY, Routledge.

Cooper, K., Bocksnick, J., \& Frick, M. (2002). Trends in working with special needs students. The Agricultural Education Magazine, 75(3), 6-7. Retrieved from https://www.naae.org/profdevelopment/magazine/archive_issues/Volume75/v75i3.pdf

Croom, B., \& Moore, G. (2004). Dumping grounds. The Agricultural Education Magazine, 77(1), 15-18. Retrieved from https://www.naae.org/profdevelopment/magazine/archive_issues/Volume77/v77i1.pdf

Crunkilton, J. R. (1985). Preparing agricultural teachers of the handicapped. The Agricultural Education Magazine, 57(8), 19-21. Retrieved from https://www.naae.org/profdevelopment/magazine/archive_issues/Volume57/v57i8.pdf

Curtis, S. M. (1975). The case for students with special needs. The Agricultural Education Magazine, 47(11), 243-244. Retrieved from https://www.naae.org/profdevelopment/magazine/archive_issues/Volume47/v47i11.pdf

Daniels, J. H., \& Walker, R. W. (1975). Handicapped and the law. The Agricultural Education Magazine, 47(11), 251, 263. Retrieved from https://www.naae.org/profdevelopment/magazine/archive_issues/Volume47/v47i11.pdf

Darling-Hammond, L. (2005). Teaching as a profession: Lessons in teacher preparation and professional development. Phi Delta Kappa, 87(3), 237-240. https://doi.org/10.1177/003172170508700318

Dawson, J. I. (1971). Making agriculture relevant for the disadvantaged. The Agricultural Education Magazine, 43(10), 242-243. Retrieved from https://www.naae.org/profdevelopment/magazine/archive issues/Volume43/v43i10.pdf

De Lay, A. M., \& Burden, M. A. (2012, May/June). Making agricultural education a special education for all learners. The Agricultural Education Magazine. 84(6), 7-8, 23. Retrieved from https://www.naae.org/profdevelopment/magazine/archive_issues/ Volume84/2012_05-06.pdf

Delks, B., \& Sillery, B. (1993). How accessible is your agriculture program?. The Agricultural Education Magazine. 65(9), 12-13, 18. Retrieved from https://www.naae.org/profdevelopment/magazine/archive_issues/Volume65/v65i9.pdf

Dieterich, C. A., \& Smith, K. (2015). The impact of special education law on career and technical education. American Secondary Education, 43(3), 60-72. Retrieved from http://web.a.ebscohost.com/ehost/pdfviewer/pdfviewer?vid=6\&sid=2931bee9-67a54d64-8aad-a5ecac1715ff\%40sessionmgr4007

Dormody, T. J., Seevers, B. S., Andreasen, R. J., \& VanLeeuwen, D. (2006). Challenges experienced by New Mexico agricultural education teachers in including special needs students. Journal of Agricultural Education, 47(2), 93-105. https://doi.org/10.5032/jae.2006.02093

Downey, R. S. (1985). Teaching the disadvantaged and handicapped. The Agricultural Education Magazine, 57(8), 5-7. Retrieved from https://www.naae.org/profdevelopment/magazine/archive_issues/Volume57/v57i8.pdf

Easterly, R. G., \& Myers, B. E. (2011). Inquiry-based instruction for students with special needs in school based agricultural education. Journal of Agricultural Education. 52(2), 36-46. https://doi.org/10.5032/jae.2011.02036 
Journal of Research in Technical Careers

Education for All Handicapped Children Act, 20 U.S.C. § 1401 (1975).

Eisenman, L. T. (2000). Characteristics and effects of integrated academic and occupational curricula for students with disabilities. Career Development for Exceptional Individuals, 23(1), 105-119. https://doi.org/10.1177/088572880002300108

Elbert, C. D., \& Baggett, C. D. (2003). Teacher competence for working with disabled students as perceived by secondary level agricultural instructors in Pennsylvania. Journal of Agricultural Education, 44(1), 105-115. https://doi.org/10.5032/jae.2003.01105

Enns, K. J., \& Martin, M. J. (2015). Gendering agricultural education: A study of historical pictures of women in the agricultural education magazine. The Journal of Agricultural Education, 56(3), 69-89. https://doi.org/10.5032/jae.2015.03069

Farmer, G. (1993). Georgia's special lamb project adoption program. The Agricultural Education Magazine, 66(6), 7, 15. Retrieved from https://www.naae.org/profdevelopment/magazine/archive_issues/Volume66/v66i6.pdf

Faulkner, P. E., \& Baggett, C. D. (2007). Why diversify the classroom? The Agricultural Education Magazine, 80(1), 13-14. Retrieved from https://www.naae.org/profdevelopment/magazine/archive_issues/Volume80/v80i1.pdf

Faulkner, P. E., \& Baggett, C. D. (2010). Preparing future secondary agricultural education teachers to work with students with learning disabilities: Reports from teacher educators. Journal of Agricultural Education. 51(3), 88-99. https://doi.org/10.5032/jae.2010.03088

Faulkner, T. L. (1968). We must serve those being neglected. The Agricultural Education Magazine, 41(3), 57, 59. Retrieved from https://www.naae.org/profdevelopment/magazine/archive_issues/Volume41/v41i3.pdf

Filson, C. H., \& Whittington, M. S. (2011). Looking through a peephole or an open door? Insights into inclusion. The Agricultural Education Magazine, 84(6), 10-11. Retrieved from https://www.naae.org/profdevelopment/magazine/archive_issues/Volume83/2011_0506.pdf

Gaona, J. (2004). The effects of the No Child Left Behind Act on career and technical education: Implications for students with special needs. Journal of Industrial Teacher Education, 41(2). Retrieved from http://scholar.lib.vt.edu/ejournals/JITE/v41n2/gaona.html

Giffing, M. D., \& Warnick, B. K. (2012). Three circle model of inclusion student, parent, and teacher success in agricultural education. The Agricultural Education Magazine, 84(6), 11-13. Retrieved from

https://www.naae.org/profdevelopment/magazine/archive_issues/Volume84/2012_0506.pdf

Giffing, M. D., Warnick, B. K., Tarpley, R. S., \& Williams, N. A. (2010). Perceptions of agriculture teachers toward including students with disabilities. Journal of Agricultural Education, 51(2), 102-114. https://doi.org/10.5032/jae.2010.02102

Good-Hamilton, R. (1985). Plants breed success. The Agricultural Education Magazine, 57(8), 8-10. Retrieved from https://www.naae.org/profdevelopment/magazine/archiveissues/Volume57/v57i8.pdf

Hamilton, D. A. (1968). Identifying the educationally handicapped. The Agricultural Education Magazine, 41(3), 66. Retrieved from https://www.naae.org/profdevelopment/magazine/archive_issues/Volume41/v41i3.pdf 
Hamilton, J. B. (1968). Guidelines for developing vocational agriculture programs for youth with special needs. The Agricultural Education Magazine, 41(3), 74-75. Retrieved from https://www.naae.org/profdevelopment/magazine/archive_issues/ Volume41/v41i3.pdf

Hamlin, H. M. (1965). The meaning of agricultural education. The Agricultural Education Magazine, 38(1), 8-9, 17, 21. Retrieved from https://www.naae.org/profdevelopment/magazine/archive_issues/Volume38/v38i1.pdf

Harlan, D. L., \& Grimes, J. W. (1968). A program for slow learners. The Agricultural Education Magazine, 41(3), 58-59. Retrieved from https://www.naae.org/profdevelopment/magazine/archive_issues/Volume41/v41i3.pdf

Higher Education Opportunity Act, Pub. L. No. 110-315 § 205, 122 Stat. 3135 (2008a).

Higher Education Opportunity Act, Pub. L. No. 110-315 § 206, 122 Stat. 3152 (2008b).

Hinders, K. (1995). Dual certification and the regular education initiative. Journal of Teacher Education, 46(3), 200-208. https://doi.org/10.1177/0022487195046003006

Hudson, F., Graham, S., \& Warner, M. (1979). Mainstreaming: An examination of the attitudes and needs of regular classroom teachers. Learning Disability Quarterly, 2, 5862. https://doi.org/10.2307/1511026

Individuals with Disabilities Education Act, Pub. L. No. 101-476, § 104 Stat. 1142 (1990).

Johnson, L., Wilson, E., Flowers, J., \& Croom, B. (2012). Perceptions of North Carolina high school agricultural educators regarding students with special needs participating in supervised agricultural experience and FFA activities. Journal of Agricultural Education, 53(4) 41-54. https://doi.org/10.5032/jae.2012.04041

Johnson, R. B., \& Christensen, L. (2014). Educational research: Quantitative, qualitative, and mixed approaches. Thousand Oaks, CA: Sage Publications, Inc.

Karten, T. J. (2008). Embracing disabilities in the classroom. New York, NY: Skyhorse Publishing.

Katsiyannis, A., Yell, M. L., \& Bradley, R. (2001). Reflections on the 25th anniversary of the Individuals with Disabilities Education Act. Remedial and Special Education, 22(6), 324-334. https://doi.org/10.1177/074193250102200602

Kessell, J., Wingenbach, G. J., \& Lawver, D. (2009). Relationships between special education confidence knowledge, and selected demographics for agricultural education student teachers. Journal of Agricultural Education, 50(2), 52-61. https://doi.org/10.5032/jae.2009.02052

Lee, J. S. (1971). Meeting the needs of the disadvantaged: Is grouping the answer? The Agricultural Education Magazine, 43(10), 250-251. Retrieved from https://www.naae.org/profdevelopment/magazine/archive_issues/Volume43/v43i10.pdf

Mack, G. L., \& Luft, V. D. (1981). Determining the extent to which mainstreaming of handicapped and disadvantaged students is accepted and used in secondary vocational agriculture programs in North Dakota. Journal of Agricultural Education, 22(2), 28-35. https://doi.org/10.5032/jaatea.1981.02028

Mallilo, A. T., Baggett, C. D., \& Curtis, S. M. (1983). Status of Pennsylvania special needs students in vocational agriculture. Journal of the American Association of Teacher Educators in Agriculture, 24(1), 34-40. https://doi.org/10.5032/jaatea.1983.01034

McDowell, W. H. (2002). Historical research: A guide. Harlow, Essex, England, UK: Pearson Education Limited.

McMillan, J. H. (2012) Educational research: Fundamentals for the consumer (6th ed.). Boston, MA: Pearson Education Limited. 
Moffitt, J. (2004, July/August). Agricultural education ... EOE? The Agricultural Education Magazine, 77(1), 12-14. Retrieved from

https://www.naae.org/profdevelopment/magazine/archive_issues/Volume77/v77i1.pdf

Moore, G. (2004). The blind man, the elephant, and agricultural education. The Agricultural Education Magazine, 77(1), 4-5. Retrieved from https://www.naae.org/profdevelopment/magazine/archive_issues/Volume77/v77i1.pdf

National Association of Agricultural Educators. (2019). What is agricultural education? Retrieved from https://www.naae.org/whatisaged/

National Center for Education Statistics. (2019). Percentage of public high schools that are regular, career/technical, and other special focus, and various characteristics of each school type: 2008. Retrieved from https://nces.ed.gov/surveys/ctes/tables/h01.asp

National FFA Organization. (2018a). FFA history. [Webpage]. Author. Retrieved from https://www.ffa.org/about/what-is-ffa/ffa-history

National FFA Organization. (2018b). Official FFA manual. Author. Retrieved from https://issuu.com/nationalffaorganization/docs/2018-19 ffa official manual

Office of Special Education and Rehabilitative Services. (2019). IDEA section 618 data products: Static tables. Washington, DC: United States Department of Education. Retrieved from https://www2.ed.gov/programs/osepidea/618-data/statictables/index.html

O'Reilly, P. A. (1975). The state planning process in vocational education: Project baseline supplemental report. Washington, DC: Office of Education (DHEW). Retrieved from https://eric.ed.gov/?id=ED119027

Ortiz, E. (1968). Greenhouse and nursery program for the mentally retarded. The Agricultural Education Magazine, 41(3), 71. Retrieved from https://www.naae.org/profdevelopment/magazine/archive_issues/Volume41/v41i3.pdf

Osborne, E. (1993). The bottom line. The Agricultural Education Magazine, 66(6), 3,6. Retrieved from https://www.naae.org/profdevelopment/magazine/archive_issues/Volume66/v66i6.pdf

Pavelock, M., \& Harlin, J. (2013). Differentiation in action: From the lesson plan to the assessment, using differentiated instruction to improve career and technology skills for the modern workplace. The Agricultural Education Magazine, 86(2), 4-6. Retrieved from https://www.naae.org/profdevelopment/magazine/archive_issues/ Volume86/2013_09-10.pdf

Phillips, B. K., \& Myers, B. (2012). Experiential and inquiry-based learning literature search. The Agricultural Education Magazine, 84(6), 9-10. Retrieved from https://www.naae.org/profdevelopment/magazine/archive_issues/Volume84/2012_0506.pdf

Roberts, T. G., Harder, A., \& Brashears, M. T. (Eds). (2016). American Association for Agricultural Education national research agenda: 2016-2020. Gainesville, FL: Department of Agricultural Education and Communication.

Rogers, E. M. (2003). Diffusion of innovations (5th ed.). New York, NY: The Free Press.

Scanlon, D. C., \& Baggett, C. D. (1985). ... Are they being served? The Agricultural Education Magazine, 57(8), 4-5. Retrieved from https://www.naae.org/profdevelopment/magazine/archive_issues/Volume57/v57i8.pdf

Smith-Hughes Act of 1917, Pub. L. No. 64-347 § 10 (1917).

Smith, K. L., \& Rayfield, J. (2019). STEM knowledge, learning disabilities and experiential learning: Influences of sequencing instruction. Journal of Agricultural Education, 60(2), 222-236. https://doi.org/10.5032/jae.2019.02222 
Stair, K. S., Moore, G. E., Wilson, B., Croom, B., \& Jayaratne, K. S. U. (2010). Identifying confidence levels and instructional strategies of high school agricultural education teachers when working with students with special needs. Journal of Agricultural Education, 51(2), 90-101. https://doi.org/10.5032/jae.2010.0209

Steed, A. T. (1971). Programs for students with special needs. The Agricultural Education Magazine, 43(10), 244-245. Retrieved from https://www.naae.org/profdevelopment/magazine/archive_issues/Volume43/v43i10.pdf

Toole, P. F., \& Eddowes, J. (1985). Support services for handicapped students. The Agricultural Education Magazine, 57(8), 10-13. Retrieved from https://www.naae.org/profdevelopment/magazine/archive_issues/Volume57/v57i8.pdf

Tyrrell, M. (1985). The land laboratory: Success for the special needs student. The Agricultural Education Magazine, 57(8), 17-18. Retrieved from https://www.naae.org/profdevelopment/magazine/archive_issues/Volume57/v57i8.pdf

United States Department of Education (USDOE). (2010). Thirty-five years of progress in educating children with disabilities through IDEA. Washington, DC: Office of Special Education and Rehabilitation Services. Retrieved from https://www2.ed.gov/about/offices/list/osers/idea35/history/idea-35-history.pdf

Wakefield, D. B., \& Talbert, B. A. (2003). A historical narrative on the impact of the New Farmers of America (NFA) on selected past members. Journal of Agricultural Education, 44(1), 95-104. https://doi.org/10.5032/jae.2003.01095

Walker, R. W. (1968). Meeting special needs of students through vocational-centered laboratory learning. The Agricultural Education Magazine, 41(3), 68-69. Retrieved from https://www.naae.org/profdevelopment/magazine/archive_issues/Volume41/v41i3.pdf

Walls, W. J. (1975). Suggestions for teaching disadvantaged and handicapped. The Agricultural Education Magazine, 47(11), 261-263. Retrieved from https://www.naae.org/profdevelopment/magazine/archive_issues/Volume47/v47i11.pdf

Warmbrod, J. R. (1968). Onlookers or active participants? The Agricultural Education Magazine, 41(3), 55-56. Retrieved from https://www.naae.org/profdevelopment/magazine/archive_issues/Volume41/v41i3.pdf

Woehler, W. (1975). Teaching the disadvantaged and handicapped. The Agricultural Education Magazine, 47(11), 245-246. Retrieved from https://www.naae.org/profdevelopment/magazine/archive_issues/Volume47/v47i11.pdf Wonacott, M. E. (2001). Students with disabilities in career and technical education. ERIC Digest. Retrieved from https://eric.ed.gov/?id=ED459324 